\title{
Biological Paternal Grandmother
}

National Cancer Institute

\section{Source}

National Cancer Institute. Biological Paternal Grandmother. NCI Thesaurus. Code C96584.

A female relative who is the biological mother of the biological father. 